\title{
Metode Pembelajaran Jarak Jauh Pada Mata Kuliah Gitar Klasik Lampung Pepadun di Prodi Pendidikan Musik, Fakultas Keguruan IImu Pendidikan, Universitas Lampung
}

\author{
Erizal Barnawi ${ }^{1}$; Afrizal Yudha Setiawan ${ }^{2}$ \\ 1,2 Prodi Pendidikan Musik, Jurusan Pendidikan Bahasa dan Seni, Universitas Lampung, Lampung, Indonesia \\ ${ }^{(*)} \bowtie$ (e-mail) erizalbarnawi@yahoo.co.id ${ }^{1}$; afrizal.yudha@fkip.unila.ac.id²
}

\begin{abstract}
Abstrak
Kesulitan dalam mempelajari latihan Gitar Klasik Lampung Pepadun disebabkan oleh beberapa faktor, antara lain; 1) proses pembelajaran tidak dibimbing langsung oleh pelatih yang ahli di bidangnya; 2) banyak mahasiswa program studi Pendidikan Musik yang belum mampu membaca notasi balok berupa lagu; 3) sebagian siswa belum memiliki keterampilan bermain gitar dengan teknik yang benar. Tujuan jangka panjang dalam pembelajaran Gitar Klasik Lampung Pepadun adalah mahasiswa mampu menjadi agen perubahan dalam melestarikan seni Gitar Klasik Lampung Pepadun dan menjadi pionir dalam mengembangkan dan menciptakan musik, baik musik kontemporer maupun musik kreatif. Target khusus yang ingin dicapai dalam penelitian ini adalah terciptanya pola pengajaran baru dalam bidang musik tradisional Lampung yaitu pembelajaran dengan menggunakan beberapa aplikasi dan metode pembelajaran jarak jauh sesuai dengan konsep pembelajaran. Beberapa metode pembelajaran online telah diterapkan dengan menggunakan berbagai aplikasi seperti Youtube, MP3, dan Sibelius. Pembelajaran online adalah pembelajaran yang dilakukan tanpa tatap muka secara langsung, dengan menggunakan perangkat smartphone/gadget/laptop, dan platform video conference sebagai ruang berlangsungnya proses pembelajaran. Namun, ketujuh komponen pembelajaran yang meliputi guru/dosen, siswa, tujuan, materi, metode, media, dan evaluasi harus tetap menjadi komponen integral dari pembelajaran online, yang akan diintegrasikan dalam mencapai tujuan pembelajaran.
\end{abstract}

Kata kunci: Gitar klasik lampung; metode pembelajaran jarak jauh, mahasiswa; pendidikan musik.

\section{Proses Artikel}

Diterima 30-09-2021; Revisi 15-12-2021; Terbit Online 19-12-2021 


\begin{abstract}
The difficulties in learning the Lampung Pepadun Classical Guitar practice are caused by several factors, including; 1) the learning process is not guided directly by trainers who are experts in their fields; 2) many students of the Music Education study program are not yet able to read block notation in the form of songs; 3 ) some students do not have the skills to play guitar with the correct technique. The long-term goal in learning Lampung Pepadun Classical Guitar is that students are able to become agents of change in preserving the art of Lampung Pepadun Classical Guitar and become pioneers in developing and creating music, both contemporary music and creative music. The specific target to be achieved in this research is the creation of a new teaching pattern in the field of Lampung traditional music, namely learning by using several applications and distance learning methods in accordance with the concept of learning. Several online learning methods have been applied using various applications such as Youtube, MP3, and Sibelius. Online learning is learning that is carried out without face to face directly, using smartphone/gadget/laptop devices, and video conferencing platforms as a space for the learning process to take place. However, the seven learning components which include teachers/lecturers, students, objectives, materials, methods, media, and evaluation must remain an integral component of online learning, which will be integrated in achieving learning objectives
\end{abstract}

Keywords: Lampung classical guitar; distance learning methods, students; music education. 


\section{Pendahuluan}

Gitar Klasik Lampung disebut dengan istilah peting tunggal, yaitu sebuah instrumen tunggal atau vocal instrumen yang dimainkan oleh satu orang saja. Konsep tersebut juga memiliki kesamaan dengan daerah lain seperti Sumatera Selatan, Jambi, dan Bengkulu. Di daerah tersebut penamaan alat musik gitar klasik disebut dengan Sahilin/Sahilinan, sedangkan di Provinsi Sulawesi Barat penyebutan gitar klasiknya yakni Sayang-Sayang Mandar (Phili dalam Ricky, 2016, p. 462). Terdapat 2 bentuk gaya gitar klasik yang berkembang di Provinsi Lampung dengan berbagai macam karakteristik khusus.

Pertama, gitar klasik Lampung Pepadun. Karakteristik dari gitar klasik Lampung Pepadun tersebut diantaranya adalah, lirik yang terkandung, teknik petikan, tuning system, dan nama petikan yang bersumber dari kecerdasaran masyarakat adat Lampung Pepadun di Provinsi Lampung. dalam penelitian sebelumnya yang di lakukan oleh penulis dalam judul "Eksistensi Gitar Klasik Lampung Tulang Bawang dan Pengembangannya". Dalam Prosiding Seminar Nasional: Temu AP2SENI 2019, (Makasar: Asosisasi Prodi Pendidikan SENDRATASIK Indonesia, 2019), Hal 52-56. Dalam Prosiding ini dibahas mengenai perkembang permainan Gitar Klasik Lampung baik dari instrumennya, kembangan dalam teknik petikan (grenek), dan penyajian Gitar Klasik Lampung dalam era modern saat ini, merupakan riset sebelumnya dari si peneliti dalam melakukan penelitian di bidang kajian Etnomusikologi yang terkhusus pada musik tradisional Lampung. Baik musik tradisional masyarakat Saibatin, maupun musik tradisional masyarakat Pepadun. Mengenai Gitar Klasik Lampung Pepadun juga di pernah dilakukan oleh peneliti Misthohizzaman, dengan judul "Gitar Klasik Lampung, Musik dan Identitas Masyarakat Tulang Bawang" dalam Tesisnya pada Jurusan Ilmu-ilmu Humaniora Program Studi Pengkajian Seni Pertunjukan dan Seni Rupa Sekolah Pascasarjana Universitas Gadjah Mada Yogyakarta, tahun 2006. Tesis ini membahas tentang sejarah gitar klasik Pepadun, unsur-unsur dasar pertunjukan gitar klasik Lampung Pepadun, Sistem Pelarasan, lagu, dan teknik petikan serta analisis pertunjukan gitar klasik Lampung Pepadun (Tulang Bawang).

Kedua, yaitu Gitar Klasik Lampung Pesisir. Diistilahkan pesisir karena wilayah masyarakat Lampung yang beradat saibatin di wilayah pesisir provinsi Lampung. Hal yang membedakan dari kedua bentuk gitar klasik tersebut adalah, tuning system, nama petikan, dan lirik yang terkandung di dalam syair peting tunggal masing-masing sub jurai di adat budaya Lampung. pernah dilakukan oleh penulis dalam penelitiannya yang berjudul "Sistem Musik Gitar Klasik Lampung Pesisir: Sebuah Kajian Ilmu Etnomusikologi yang telah terbit di jurnal elektronik JOMSTI Volume 4 Nomor 1 tahun 2021 ISI Denpasar Bali. Penelitian ini terfokus pada sejarah riwayat Gitar klasik Lampung Pesisir dan pembedahan pada notasinotasi lagu yang dimainkan oleh beberapa seniman ternama di masyarakat Pesisir Lampung seperti seniman Hila Hambala, Edi Pulampas, dan Imam Rozali. Lagu-lagu yang dibedah yakni: 1) Hila Hambala yang berjudul Tepik Tanggungan; 2) Edy Pulampas yang berjudul Anak Ngukha; dan 3) Imam Rozali yang berjudul Kumbang Kupi. Selain itu, temuan pada penelitian ini yakni sistem pelarasan Gitar Klasik Lampung di masyarakat pesisir ada 4 sistem tuningnya 1) Stem Salimpat; 2) Stem Gung Sai; 3) Stem Tiga Serangkai; dan 4) Stem Batang Hari Sembilan. 
Masyarakat Lampung terdiri dari dua jurai (sub etnis) yang dibedakan berdasarkan dialek bahasanya. Kedua sub etnis tersebut yaitu Pepadun dan Saibatin. Jurai Pepadun yang berkediaman di daerah pedalaman Lampung terdiri dari masyarakat adat Abung (Abung Siwo Migo), Pubian (Pubian Telu Suku), Tulang Bawang (Megow Pak Tulang Bawang), Bunga Mayang (Sungkai) dan Way Kanan (Buai Lima) (Sabaruddin, 2012: 60) . Sedangkan jurai Saibatin berkediaman di sepanjang pesisir, termasuk masyarakat adat Krui, Peminggir Semaka, Peminggir Pemanggilan, Peminggir Teluk, Meninting, Ranau (Muara Dua), Komering (Kayu Agung), dan Cikoneng (Banten) (Iskar, 2012, p. 160-161).

Batasan arti terhadap kata klasik dalam gitar klasik Lampung adalah sederhana, serasi, tidak berlebihan, mempunyai nilai atau mutu yang diakui, dan menjadi tolak ukur serta terikat kepada tradisi. Di samping itu, gitar klasik Lampung seperti juga teknik petikan dawai pada gitar klasik Barat, hanya mengenal teknik petikan satu persatu nada dan tidak ada nada yang dibunyikan secara bersama untuk membentuk akord, hal inilah yang menyebabkan genre kesenian ini diberi nama gitar klasik Lampung, dan ini dibenarkan oleh para pelaku seniman pendukung gitar klasik Lampung (Cikdin, Wawancara, 09 Januari 2020 dan Daman Hori, 10 Februari 2020). Raja Tihang Aneu dan Abu Tholib Khalik berpendapat, bahwa nama klasik di dapat karena muatan syair dalam gitar klasik Lampung yang penuh dengan nilai-nilai social dan ajaran agama, sehingga dianggap sangat bermutu. Gitar klasik Lampung juga dikenal dengan nama lain, yaitu gitar tunggal, karena dapat dimainkan hanya dengan satu gitar saja (Wawancara, 25 Januari 2020).

Gitar klasik lampung sebagai salah satu alat musik yang menjadi ciri khas masyakarat Lampung menjadi wajib untuk diajarkan di berbagai jenjang pendidikan, termasuk jenjang perguruan tinggi. Namun demikian, adanya pandemic Covid-19 menyebabkan pembelajaran harus dilakukan secara daring. Berdasarkan permasalahan tersebut, maka diperlukan sebuah penelitian untuk mengkaji dan mengetahui metode pembelajaran yang tepat untuk mengajar gitar klasik lampung secara daring berdasarkan komponen-komponen pembelajaran.

Penelitian ini bertujuan untuk: 1) mengidentifikasi sejauh mana pengaruh penggunaan beberapa aplikasi dalam pembelajaran jarak jauh terhadap kemampuan memainkan Gitar Klasik Lampung Pepadun; 2) Menggali persepsi mahasiswa tentang penggunaan aplikasi dalam bentuk pembelajaran jarak jauh pada pembelajaran Gitar Klasik Lampung Pepadun. Secara umum, tujuan penelitian ini adalah mengidentifikasi sejauh mana pengaruh pendukung pembelajaran penggunaan aplikasi seperti youtube dan sibelius yang dikembangkan oleh dosen mata kuliah untuk melaksanakan pembelajaran terhadap kemampuan mahasiswa dalam memainkan alat musik Gitar Klasik Lampung Pepadun.

Rumusan Masalah dari penelitian metode pembelajaran jarak jauh pada mata kuliah Gitar Klasik Lampung Pepadun di Prodi Pendidikan Musik, Fakultas Keguruan Ilmu Pendidikan, Universitas Lampung yakni bagaimana metode pembelajaran jarak jauh pada mata kuliah gitar klasik Lampung diterapkan. Selain itu, untuk kontribusi terhadap ilmu pengetahuan di dunia pendidikan musik yakni memberikan nilai tawar dalam pola pengajaran baru ketika di masa pandemi untuk meminimalisir penyebaran Covid-19. Serta, memicu kepekaan pendengaran (solfegio), memicu ketelitian dalam melihat dan membaca notasi di dalam lagu atau petikan pada Gitar Klasik Lampung Pepadun. 


\section{Metode}

Metode yang digunakan dalam penelitian ini adalah mix method, yaitu metode penelitian kuantitatif dan kualitatif. Metode kuantitatif digunakan untuk mengetahui peningkatan hasil belajar mahasiswa menggunakan one group pretest-postest design, sedangkan metode kualitatif digunakan untuk menggali informasi tentang persepsi mahasiswa melalui wawancara. Subyek penelitian ini adalah mahasiswa S1 Program Studi Pendidikan Musik, FKIP, Universitas Lampung. Satu kelas terdiri dari 32 orang mahasiswa yang menempuh mata kuliah Musik Nusantara III (Gitar Klasik Lampung Pepadun).

Teknik Pengumpulan data yang digunakan yakni: 1) Performance Test, digunakan untuk mengetahui keterampilan mahasiswa dalam memetik gitar klasik, sebelum dan sesudah diberikan treatment. 2 bentuk tes yang digunakan yaitu pretest dan posttest; 2 ) Wawancara, dilakukan untuk mengetahui persepsi mahasiswa/i terhadap proses pembelajaran jarak jauh Gitar Klasik Lampung Pepadun dengan menggunakan aplikasi youtube dan silbelius. Dalam hal ini mahasiswa diberikan beberapa pertanyaan mengenai proses pembelajaran jarak jauh pada umumnya dan proses pembelajaran yang diberikan dengan menggunakan media aplikasi youtube dan sibelius.

Teknik Analisis Data Kajian penelitian ada beberapa tahapan yang dilakukan, yakni; 1) Hasil tes petikan gitar dan teknik vocal mahasiswa di nilai berdasarkan hasil video yang dibuat oleh mahasiswa yang benar dan sesuai yang digunakan untuk tes awal dan akhir; 2) Data progres atau perkembangan mahasiswa dalam memainkan gitar klasik lampung diolah dengan menggunakan reduksi data dengan menginput masukan data wawancara mahasiswa terlebih dahulu baru dikrucutkan mengambil kesimpulan inti; 3) Hasil wawancara dianalisa dengan menjabarkan pendapat mahasiswa terkait pembelajaran daring menggunakan aplikasi youtube dan sibelius yang sudah direkam.

\section{Hasil}

Formulasi yang di terapkan dalam metode pembelajaran jarak jauh untuk praktik Gitar Klasik Lampung Pepadun adalah dengan menggunakan beberapa aplikasi. Beberapa aplikasi tersebut diantaranya adalah zoom dan youtube yang terfokuskan pada akun youtube dosen pengampu, serta aplikasi sibelius yang digunakan oleh dosen dan mahasiswa dalam memudahkan memetik dan bernyanyi. Aplikasi sibelius digunakan karena aplikasi tersebut memiliki fitur notasi balok yang dapat memudahkan mahasiswa untuk melakukan kegiatan praktik. Dengan menggunakan aplikasi Sibelius dalam pembelajaran, mahasiswa dapat secara langsung mengetahui nada dan irama dalam petikan Sai Kres di stem Be pada alat musik gitar masing-masing.

\section{Komponen Pembelajaran Jarak Jauh Pada Gitar Klasik Lampung Pepadun}

Guru/ pengajar, yaitu pihak yang menciptakan lingkungan belajar untuk peserta didik sebagai subjek belajar. Guru memiliki peran sebagai demonstrator, fasilitator, pengelola kelas, dan evaluator dalam proses pembelajaran. Sebagai pengajar dalam hal ini adalah dosen pengampu mata kuliah ialah Erizal Barnawi, S.Sn, M.Sn. Pada perkuliah di semester Ganjil tahun ajaran 2020/2021 Program Studi Pendidikan Musik, peneliti telah melakukan demonstrasi langsung mempraktikkan teknik petikan di dalam kelas online, memfasilitasi mahasiswa dalam memudahkan praktik bermain gitar klasik dan bernyanyi, serta mengelola 
kelas untuk secara bergantian dari tiap-tiap mahasiswa yang praktik memainkan gitar klasik Lampung Pepadun untuk dibimbing dan diarahkan, serta mengadakan evaluasi secara menyeluruh akan untuk mengetahui perkembangan masing-masing mahasiswa dalam melakukan praktik di akhir kegiatan pembelajaran.

Siswa, yaitu subjek belajar yang memiliki tujuan untuk mengembangkan segenap potensi yang ada pada dirinya, melalui serangakain proses pembelajaran. Dalam proses pembelajaran siswa adalah subjek belajar yang memiliki tujuan dan ingin mencapainya secara optimal. Oleh sebab itu, mahasiswa yang terlibat dalam kegiatan pembelajaran adalah berjumah 32 mahasiswa sebagai subjek belajar karena mereka yang mengambil mata kuliah Musik Nusantara III.

Tujuan pembelajaran, yaitu rumusan luas mengenai hasil-hasil yang diinginkan, yang di dalamnya tertulis indikator keberhasilan yang harus dicapai oleh peserta didik dalam serangkaian proses pembelajaran. Tujuan pembelajaran Gitar Klasik Lampung Pepadun ini ialah untuk mengetahui sejauh mana tingat kesulitan mahasiswa dalam melakukan praktik gitar dan bernyanyi. Indikator yang diberikan oleh peneliti atas dasar masukan oleh mahasiswa yakni indikatornya: teknik petikan, penyeteman senar gitar ke steam Be yang ada di gitar klasik Lampung Pepadun, pelafalan bahasa Lampung Pepadun berdialek $\mathrm{O}$, bagianbagian tema lagu di dalam petikan Sai Kres, pembacaan notasi pada lagu Sai Kres.

Materi / bahan ajar, yaitu segala sesuatu yang menjadi isi dari kurikulum yang harus dikuasai oleh peserta didik sebagai bentuk pencapaian kompetensi yang diharapkan. Dalam hal ini, materi atau bahan ajar yang diberikan oleh dosen pengampu dalam mata kuliah Musik Nusantara III (Gitar Klasik Lampung Pepadun) yakni Petikan Sai Kres dengan Steman Gitarnya ialah Steam Be. Lirik lagu yang digunakan pun untuk memudahkan mahasiswa di ambil dari salah satu karya seniman Lampung yakni Bapak Supirman dengan judul lagu Anti Narkoba. Adapun materi ajarnya yakni tertera di bawah ini.

$\begin{array}{ll}\text { Lagu } & \text { : Anti Narkoba } \\ \text { Petikan } & : \text { Sai Kris } \\ \text { Stem } & : \text { Be } \\ \text { Vocal } & : \text { Supirman } \\ \text { Ciptaan } & : \text { Supirman } \\ \text { Tahun Cipta } & : \text { : } 2016 \\ \text { Link youtube } & : \text { http://youtu.be/vscxy34mZG8 } \\ \text { Hp } & : \text { (+62 821-7995-3033/+62 821-8044-5622) } \\ \text { Suku } & : \text { Lampung Abung Siwo Migo (0) Kepenyimbangan }\end{array}$




\section{LIRIK LAGU}

Ngenah di jaman tano

Dunia tambah jadei... $2 x$

Generasi anak mudo

Rasan sai nyalei-nyalei... 2x

Penyakit no narkoban

Mak milih basing umat... 2x

Tuho ataupun Mudo

Pejabat masyarakat... 2x

Pengaruh makai narkoba

Yo nyadang kepikiran... 2x

Bagi sai anak mudo

ngeguwai kejahatan... $2 x$

Pengatew kilu tulung

Di unyen gham kirei kanan... $2 x$

Jamo gham dukung

Ngebasmi kejahatan... 2x

Diunyen kanan kirei

Metei dang cubo-cubo... 2x

Lamen Kak kuwuk buwei

Nendou badan gham sagho... $2 x$
Salah ngeguwai rasan salah

Ngelanggar hukum agamo... 2x

Bukti no ghadew nayah

macem2 narkoba... 2x

Mulai minuman keras

Sabu ganja extasi... $2 x$

Aparat harus tegas

Operasi dijo dinei... $2 x$

Ngeguwai kejahatan

Tian Mak gabai matei... 2x

Kak nayah kejadian

ngebigal dijo dinei... $2 x$

Adat budayo Lampung

pakai Piil Pasenggirei... 2x

Unyen gham jimo Lampung

Narkoba tulung hindari... $2 x$

Pengatew kilu tulung

Unyen gham kirei kanan... 2x

Jamo-jamo gham dukung

Ngebasmei kejahatan... 2x

Terjemahan Bebas...

Lihat jaman sekarang

dunia makin menjadi-jadi

generasi anak muda

kerjaannya aneh-aneh
Membuat kerjaan salah

melanggar hukum agama

contohnya sudah banyak

macem-macem narkoba 
Penyakitnya narkoba

tidak memilih generasi

tua atau pun muda

pejabat atau masyarakat

Pengaruh memakai narkoba

merusak pikiran

bagi anak muda

membuat kejahatan

\section{Mohon pertolongan}

semua kita, kiri-kanan (sekeliling)

sama sama kita dukung

membasmi kejahatan

Semua kita kanan-kiri (sekeliling)

kalian jangan coba coba

kalau sudah masuk penjara

membuat badan kita susah
Mulai minuman keras

sabu, ganja, extacy

aparat harus tegas

operasi disana sini

Membuat kejahatan

mereka tidak takut mati

sudah banyak kejadian

ngebegal disana sini

Adat budaya Lampung

pakai piil pasenggiri (Falsafah Lampung)

semua kita penduduk Lampung

narkoba tolong hindari 
Acoustic Guitar Acoustic Guitar

Stem Be: $1=\mathrm{e} ; 2=\mathrm{b} ; 3=\mathrm{g} ; 4=\mathrm{d} ; 5=\mathrm{A} ; 6=\mathrm{G}$
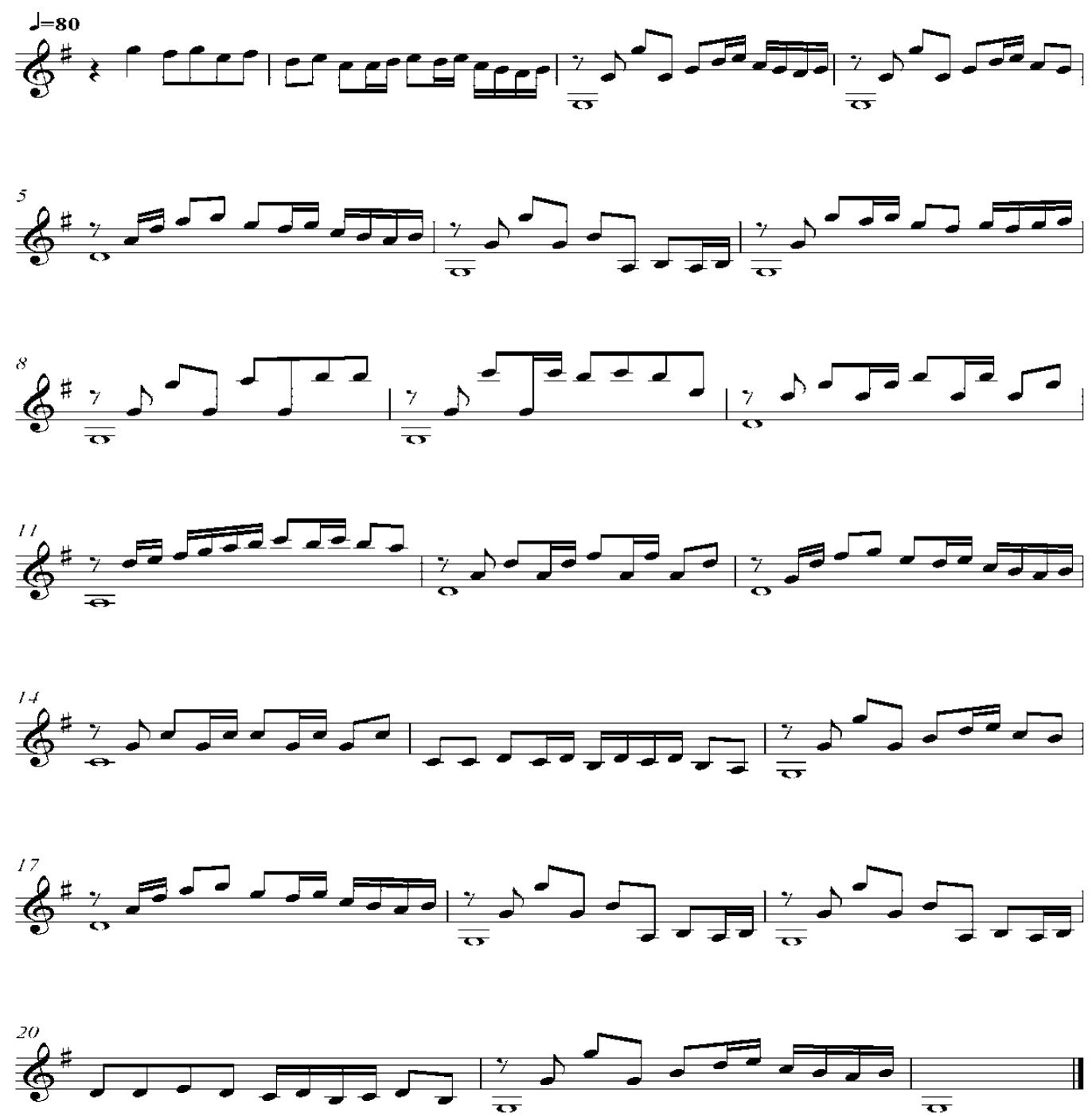

Gambar 1. Notasi petikan Sai Kres/Satu Kres yang di trankripsikan dari petikan yang dilakukan oleh seniman Gitar Klasik Lampung Pepadun Bapak Supirman pada tahun 2021.

Metode pembelajaran yang digunakan oleh guru/pengajar dalam melaksanakan kegiatan belajar mengajar, lebih khusus dalam menyampaikan materi pembelajaran. Metode pembelajaran yang diterapkan oleh dosen pengampu yaitu metode presentasi dan metode ceramah. Selain itu, metode tutor sebaya digunakan kepada mahasiswa antar mahasiswa dengan tujuan untuk memberikan semangat kebersamaan dalam belajar dan membantu mahasiswa yang mengalami kesulitan dalam mempelajari materi perkuliahan.

Media pembelajaran, yaitu segala sesuatu yang dapat digunakan untuk menyampaikan pesan atau materi pembelajaran kepada peserta didik, sehingga peserta didik mampu belajar dengan mudah, efektif, dan efisien, serta proses pembelajaran dapat berjalan dengan kondusif. Untuk itu, media yang digunakan dalam pembelajaran jarak jauh ini yakni dengan 
aplikasi Whatsapp sebagai media komunikasi antar dosen dengan mahasiswa, atau mahasiswa dengan mahasiswa. Adapun media pembelajaran yang digunakan untuk melakukan tutorial online yaitu dengan aplikasi video conference, zoom meeting. Untuk materi ajar sebagai bahan pembelajaran di berbagai tempat (kondisional) yakni dengan menggunkan aplikasi youtube yang mudah diakses oleh mahasiswa karena telah diberikan link dalam akun pribadi dosen pengampu mata kuliah. Terakhir aplikasi sibelius yang terinstal secara offline di komputer maupun PC tiap-tiap mahasiswa untuk memudahkan solfegio dan primavista dalam membaca dan mendengar notasi lagu dari petikan Sai Kreas Steam Be pada Gitar Klasik Lampung Pepadun.

Evaluasi kegiatan yang dilakukan untuk mengetahui tingkat keberhasilan dari proses pembelajaran yang telah dilakukan. Kegiatan evaluasi menggunakan metode pretest-posttest untuk mengukur kemampuan mahasiswa dan setelah diterapkan metode pembelajaran berbasis aplikasi daring pada pembelajaran Gitar Klasik Lampung Pepadun.

\section{Hasil Pretest-Posttest}

Pretest merupakan tes awal yang dilakukan untuk mengukur kemampuan awal mahasiswa dalam memainkan instrument gitar tunggal. Dalam hal ini mahasiswa belum diberi treatment berupa metode pembelajaran daring dengan berbagai aplikasi penunjang. Indikator penilaian dilakukan dengan pernyataan "mampu" atau "tidak mampu" dalam memainkan instrument. Pengukuran dilakukan dengan fokus kemampuan mahasiswa memainkan instrument gitar secara primavista (membaca partitur lagu secara langsung). Berdasarkan hasil pengukuran pada pretest diperoleh data bahwa persentase kemampuan mahasiswa dalam memainkan instrument adalah sebesar $21.87 \%$ dari jumlah keseluruhan mahasiswa.

Posttest dilakukan untuk mengetahui hasil kemampuan mahasiswa secara keseluruhan setelah adanya penerapan metode pembelajaran jarak jauh. Adapun treatment yang dilakukan adalah dengan mengimplementasikan aplikasi "Youtube dan sibelius" dilakukan dengan menggunakan platform Whats App group sebagai media komunikasi dalam membagikan notasi pembelajaran Gitar Klasik Lampung Pepadun (melalui link youtube, pdf notasi, dan file notasi sibelius). Berdasarkan hasil posttest yang dilakukan, ketercapaian pembelajaran daring pada mata kuliah gitar klasik lampung dengan penerapan metode pembelajaran daring adalah sebesar $62.5 \%$. Dengan demikian terdapat peningkatan persentase ketercapaian pembelajaran pada posttest yaitu sebesar 40.63\%. Adapun perbandingan nilai pretest dan posttest dapat dilihan pada diagram berikut.

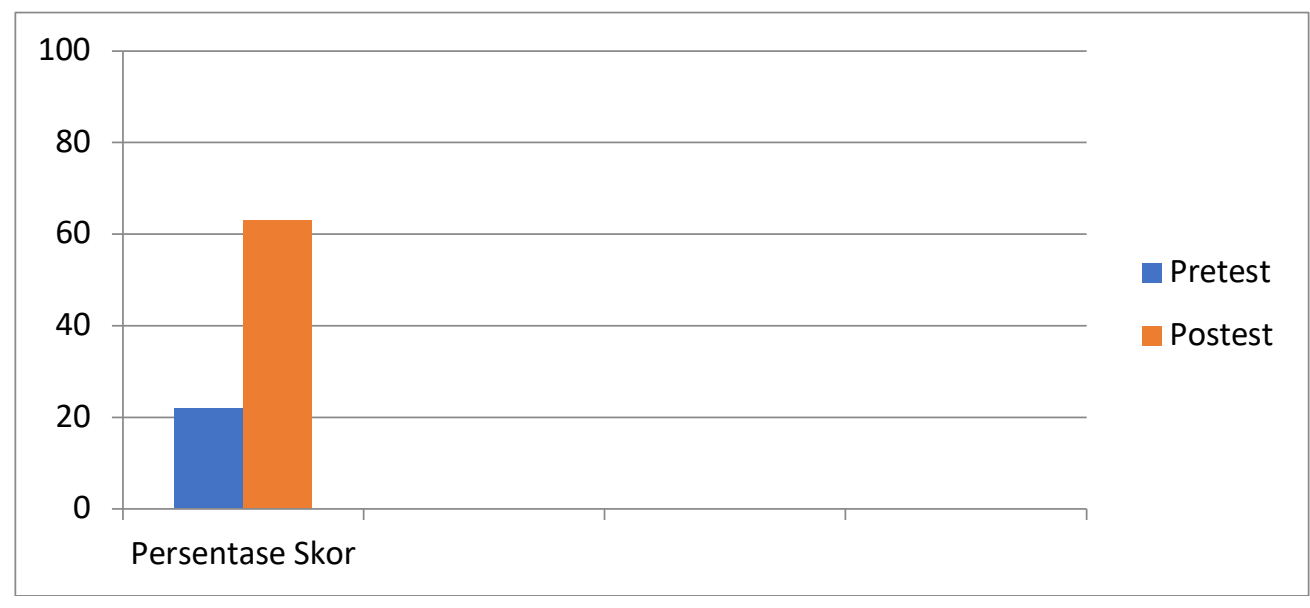


Berdasarkan diagram tersebut terdapat peningkatan kemampuan mahasiswa dalam pembelajaran gitar klasik klasik lampung. Jumlah subjek penelitian yang mampu memainkan gitar klasik lampung pada tahapan pretest adalah sebanyak 7 orang, sedangkan jumlah subjek penelitian yang mampu memainkan gitar klasik lampung pada posttest adalah sebanyak 20 orang. Dengan demikian dapat disimpulkan bahwa penerapan metode pembelajaran jarak jauh dengan menggunakan berabagai media seperti youtube, zoom meeting, Sibelius, dan WhatsApp Group mampu meningkatkan keterampilan mahasiswa.

\section{Pembahasan}

\section{Konsep Pembelajaran Daring}

Hakikatnya pembelajaran adalah suatu usaha sadar yang dilakukan oleh pengajar untuk membantu subjek belajar (siswa/ peserta didik/ mahasiswa), agar subjek tersebut dapat belajar sesuai dengan kebutuhan dan minatnya (Kustandi \& Darmawan, 2020. p. 1). Pembelajaran juga dapat dimaknai sebagai suatu usaha untuk menciptakan suasana belajar, dimana sesorang dapat dikatakan belajar apabila terdapat perubahan tingkah laku dalam dirinya, yang mencakup 3 aspek perubahan yaitu perubahan pada bidang kognitif, afektif, dan psikomotorik (Siregar, Eveline \& Nara, 2014, p. 3). Dengan demikian kegiatan pembelajaran sebagai ruang untuk menciptakan suasana belajar semestinya selalu berorientasi pada pencapaian ketiga ranah perubahan tingkah laku tersebut secara optimal.

Ruhimat (2013, p. 147) menyebutkan beberapa macam komponen pembelajaran diantaranya adalah sebagai berikut: 1) Guru / pengajar, yaitu pihak yang menciptakan lingkungan belajar untuk peserta didik sebagai subjek belajar. Guru memiliki peran sebagai demonstrator, fasilitator, pengelola kelas, dan evaluator dalam proses pembelajaran (Usman \& Lilis, 2012, p. 9-12); 2) Siswa, yaitu subjek belajar yang memiliki tujuan untuk mengembangkan segenap potensi yang ada pada dirinya, melalui serangakain proses pembelajaran. Dalam proses pembelajaran siswa adalah subjek belajar yang memiliki tujuan dan ingin mencapainya secara optimal (Ruhimat, 2013, p. 147); 3) Tujuan pembelajaran, yaitu rumusan luas mengenai hasil-hasil yang diinginkan, yang di dalamnya tertulis indikator keberhasilan yang harus dicapai oleh peserta didik dalam serangkaian proses pembelajaran (Hamalik, 2014, p. 76); 4) Materi / bahan ajar, yaitu segala sesuatu yang menjadi isi dari kurikulum yang harus dikuasai oleh peserta didik sebagai bentuk pencapaian kompetensi yang diharapkan (Ruhimat, 2013, p. 147); 5) Metode pembelajaran, yaitu cara yang digunakan oleh guru / pengajar dalam melaksanakan kegiatan belajar mengajar, lebih khusus dalam menyampaikan materi pembelajaran (Ruhimat, 2013, p. 147); 6) Media pembelajaran, yaitu segala sesuatu yang dapat digunakan untuk menyampaikan pesan atau materi pembelajaran kepada peserta didik, sehingga peserta didik mampu belajar dengan mudah, efektif, dan efisien, serta proses pembelajaran dapat berjalan dengan kondusif (Asyhar, 2012, p. 8); 7) Evaluasi, yaitu kegiatan yang dilakukan untuk mengetahui tingkat keberhasilan dari proses pembelajaran yang telah dilakukan. (Ruhimat, 2013, p. 147).

Ketujuh komponen pembelajaran tersebut merupakan satu kesatuan yang harus ada dalam setiap proses pembelajaran. Inti dari proses pembelajaran adalah tercapainya tujuan belajar yang telah ditetapkan, namun ketercapaian tersebut harus dilakukan secara efektif 
dan efisien, serta terorganisir dengan baik. Adanya komponen-komponen pembelajaran tersebut dapat mencapai tujuan belajar secara optimal.

Selanjutnya, perkembangan teknologi yang kian pesat memberikan dampak yang cukup signifikan pada pelaksanaan proses pembelajaran, salah satunya adalah pembelajaran daring (dalam jaringan). Pembelajaran daring dapat didefinisikan sebagai bentuk kegiatan pembelajaran yang dilaksanakan tanpa adanya tatap muka (no face to face learning), dan seluruh aktivitas pembelajaran dilaksanakan dengan bantuan koneksi internet (Dabbagh, Marra, \& Howland, 2018, p. 1). Hal ini merupakan bentuk kegiatan pembelajaran yang berorientasi pada kemajuan teknologi di era revolusi industri 4.0. Manusia tidak lagi membutuhkan ruang untuk bertatap muka guna melaksanakan proses pembelajaran, segala sesuatunya dapat dilakukan melalui jarak jauh, namun suasana belajar tetap dapat dilaksanakan. Namun demikian, tugas terpenting dalam pembelajaran adalah adalah bagaimana guru dapat mendesain proses pembelajaran daring secara bermakna, dengan memperhatikan beberapa komponen seperti strategi instruksional, aktivitas pembelajaran, dan teknologi yang dapat mendukung untuk mencapai pembelajaran yang bermakna tersebut (Dabbagh, Marra, \& Howland, 2018: 2). Ketujuh komponen pembelajaran yang telah disebutkan sebelumnya, harus tetap menjadi kesatuan komponen dalam proses pembelajaran daring.

Segala aktivitas pembelajaran daring dilaksanakan dengan menggunakan jaringan internet, oleh sebab itu pembelajaran daring sangat berhubungan dengan penggunakan media dan teknologi. Salah satu teknologi yang banyak dimanfaatkan untuk melaksanakan pembelajaran daring adalah teknologi mobile dengan penggunaan smartphone. Kolb (2008) mengatakan bahwa "There are many ways that cell phone can be integrated into formal classes, that are: 1 ) access information from the internet; 2 ) communicate with classmate or teachers; 3 ) record or take notes; 4) leran about asssignments or activities; 5) create or share documents or media; 6 ) take photos or videos for class assignments; and coordinate schedule or activities (Moor \& Kearsley, 2011: 86). Dengan demikian, pembelajaran daring dengan memanfaatkan smartphone menjadi salah satu cara untuk membangun komunikasi antara pengajar dengan subjek dalam proses pembelajaran. Namun demikian, hal terpenting yang menjadi tanggungjawab bagi seorang dosen adalah menumbuhkan motivasi belajar mahasiswa, ketika proses perkuliahan praktik Gitar tersebut dilaksanakan secara online dengan bantuan teknologi mobile berupa smartphone.

Smartphone atau laptop merupakan tool yang digunakan untuk melaksanakan kegiatan pembelajaran daring, namun demikian dibutuhkan media sebagai ruang belajar dalam melakukan proses pembelajaran daring, yakni platform video conference. Video conference merupakan bentuk perkembangan teknologi yang memungkinkan beberapa individu tergabung dalam satu ruang secara virtual. Hal ini dapat diasumsikan sebagai sebuah kelas belajar untuk berlangsungnya proses pembelajaran. Adapun platform video conference yang umum digunakan dalam proses pembelajaran adalah zoom meeting, dan google meet.

Berdasarkan beberapa konsep yang telah dikemukakan maka dapat ditarik sebuah kesimpulan bahwa pembelajaran daring adalah pembelajaran yang dilakukan tanpa tatap muka secara langsung, dengan menggunakan smartphone / gadget/ laptop sebagai perangkat, dan platform video conference sebagai ruang untuk berlangsungnya proses 
pembelajaran. Namun demikian, ketujuh komponen pembelajaran yang meliputi guru/pengajar/dosen, siswa/mahasiswa, tujuan, materi, metode, media, dan evaluasi harus tetap menjadi kesatuan komponen dalam pembelajaran daring, yang akan terintegrasi dalam pencapaian tujuan belajar yang dibutuhkan oleh subjek belajar.

\section{Kesimpulan}

Hasil dari penelitian ini menunjukkan bahwa adanya peningkatan pencapaian nilai mahasiswa dalam hal fluency/kelancaran dalam memainkan gitar setelah diajar dengan menggunakan beberapa platform. Hal ini dikarenakan mahasiswa merasa termotivasi dengan implementasi platform (youtube, sibelus) di dalam pembelajaran secara online. Menurut mahasiswa sebagai subjek penelitian, platform tersebut cukup efektif untuk mencipatakan suasana pembelajaran yang menyenangkan. Selain itu platform tersebut juga memotivasi mereka untuk bisa memperkaya metari ajar baik itu yang sudah mereka ketahui sebelumnya maupun yang belum mereka ketahui untuk memudahkan dalam pembelajaran musik. Dari hasil penelitian ini juga, disarankan kepada para guru musik tradisional Lampung khususnya guru yang mengajar alat musik Gitar Klasik Lampung Pepadun untuk dapat mengimplementasikan platform (youtube dan Sibelius) di dalam proses pembelajaran jarak jauh. Selain itu pula platform lain yang mendukungnya yakni, aplikasi grup whats app, dan aplikasi zoom premier.

\section{Referensi}

Asyhar, Rayandra. (2012). Kreatif Mengembangkan Media Pembelajaran. Jakarta: Referensi Jakarta.

Dabbagh, N. Marra, R.M., \& Howland, J.L. (2018). Meaningful Online Learning Integrating Strategies, Activities, and Learning Technologies for Effective Designs. Routledge.

Departemen Pendidikan Nasional, (2002). Kamus Besar Bahasa Indonesia. Jakarta: Balai Pustaka

Don Michael Randel, ed., (1986). The New Harvard Dictionary f Music. London: The Belknap Press of Harvard University Press.

Barnawi, E., Pamungkas, B., Prayoga, M. R. D., \& Yoga, M. (2021). Gitar Klasik Lampung Pesisir: Pola Permainan dan Sistem Penalaannya. Journal of Music Science, Technology, and Industry, 4(2), 233-249.

Barnawi, E. (2019). Eksistensi Gitar Klasik Lampung Tulang Bawang dan Pengembangannya. Dalam Prosiding Seminar Nasional: Temu AP2SENI 2019, (Makkasar: Asosisasi Prodi Pendidikan SENDRATASIK Indonesia, 2019), Hal 52-56

Kustandi, C., \& Darmawan, D. (2020). Pengembangan Media Pembelajaran. Jakarta: Kencana. Hamalik, O. (2014). Kurikulum dan Pembelajaran. Jakarta: Bumi Aksara.

Iskar, (2012). Kamus Bahasa Lampung Aksara Edisi 2. Bandar Lampung: Smart Cipta Intelekta.

Misthohizzaman. (2006). Gitar Klasik Lampung, Musik dan Identitas Masyarakat Tulang Bawang (Tesis untuk meraih gelar S2 pada Jurusan IImu-ilmu Humaniora Program Studi Pengkajian Seni Pertunjukan dan Seni Rupa Sekolah Pascasarjana Universitas Gadjah 
Mada Yogyakarta, 2006).

Moor, M.G., Kearsley, G. (2011). Distance Education: A Systems View of Online Learning. USA: Wadsworth.

Irawan, Ricky. (2013). Ritme Inti Pada Gambus Dan Gitar Lampung Pesisir : Sebuah Kajian Transformasi Musikal di sampaikan dalam prosiding pada acara "Konferensi Internasional VI, Bahasa, Sastra, dan Budaya Daerah. Lampung 24-26 September 2016 (Lampung: Ikatan Dosen Budaya Daerah Indonesia Komisariat Lampung), 461Ruhimat, Toto. Tim Pengembang MKDP Kurikulum dan Pembelajaran. 2013. Kurikulum dan Pembelajaran. Jakarta: Rajawali Pers.

Sabaruddin. (2012). Lampung Pepadun dan Saibatin/Pesisir - Dialek O/Nyow dan Dialek A/Api Jakarta: Buletin Way Lima Manjau.

Siregar, Eveline, \& Nara. (2014). Teori Belajar dan Pembelajaran. Bogor: Ghalia Indonesia.

Usman, M.U., \& Lilis, S. (2012). Upaya Optimalisasi Kegiatan Belajar Mengajar. Bandung: PT. Remaja Rosdakarya.

Pono Banoe, (2003). Kamus Musik. Yogyakarta: Kanisius. 